\title{
Mathematics Departmental Strategic Plan: The Case of Mufulira College of Education
}

\author{
Dennis Kambilombilo ${ }^{1} \&$ Mr. Rene Lessen ${ }^{1}$ \\ ${ }^{1}$ Mufulira College of Education, P.O Box 40400, Mufulira, Zambia \\ Correspondence: Dennis Kambilombilo, P.O Box, 40400, Mufulira, Zambia. \\ E-mail; dennischali@rocketmail.com
}

Received: February 9, 2015

Accepted: March 23, 2015

Available online: April 24, 2015

doi:10.11114/ijsss.v3i3.791

URL: http://dx.doi.org/10.11114/ijsss.v3i3.791

\begin{abstract}
The purpose of this study was to find out why the mathematics department at Mufulira College of Education (MUCE) does not use strategic planning in its planning. A case study was undertaken at MUCE, a public college on the Copperbelt province of Zambia. The research was conducted on twenty two (22) mathematics students, five (5) mathematics lecturers and the client organization (Principal). In total, the sample size was 28 as already tabulated above.

Questionnaires were used to collect data for this study. The research design used for this study was a mixed survey method. Data collected were analyzed quantitatively using the Likert's 5 Scale model. The results obtained reviewed that mathematics lecturers had little or limited knowledge of strategic planning. The findings of the study indicated that, the department has had no written strategic plan since it was upgraded as a secondary school teacher training college in 2008. Consequently, the current planning system is not near organized strategic planning. To this effect, the department needs to develop a strategic plan for improved performance.
\end{abstract}

Keywords: Departmental strategic planning, public teacher training college

\section{Introduction}

\subsection{Short Description of the Institution}

Mufulira College of Education (MUCE) is one of the public (Government) secondary teachers training college; training teachers to teach at junior secondary school level. It was opened in 1963 as a primary teacher training college and was upgraded in 2008 to the current status. It is located along Mufulira- Kitwe road opposite Kamuchanga police station about 8 kilometers from town centre. The college is a government run college: that is, government decides the programmes to be offered and the students to be enrolled each academic year. It employs and pays salaries to the academic staff as well as some auxiliary staff. In this way, the college management has limited powers to manage the affairs of the college.

The college offers a three year secondary teachers' diploma in Physical Education (P.E)/Art, P.E /Music, Home Economics (H.E), Mathematics and Science. In addition, the college offers compulsory educational subjects. These subjects include; Psychology of Education, Theory \& Practice (T.P), History \& Philosophy of Education (H.P.E) and Sociology of Education (S.E). Art, Music, P.E and Home Economics fall under one department called Practical department. Thus, students can pursue a course in Mathematics, Science, Home Economics, P.E \& Art or P.E \& Music. At the moment the college runs two progammes: Regular and Open and Distance Learning (ODL) for pre-service students and in-service teachers respectively. For the Regular school, the college has about 1,500 students (500 students per in-take) and 1800 students for ODL (600 per in-take).

In terms of staffing, the college has adequate number and qualified staff to run the programmes. Currently there are 43 teaching staff with a minimum qualification of a first degree in the teaching subject and 30 non - academic staff. All the teaching staff are employed by the government.

The college is currently headed by a female principal, Mrs. Grace Chilekwa who is assisted by Mr. Dominic Yumba. The principal has a masters' degree in Business Administration (MBA) while the vice principal has a masters' in Public Administration (MPA). These officers were appointed by the Teaching Service Commission on behalf of the Ministry of 
Education, Science, Vocational Training, and Early Child Education (MESVTEE). The college has a College Board comprising members from the community, college staff and student representatives.

\subsection{Introduce the Problem}

Strategic planning has not been part of educational institutions for a long time. This has particularly been the case in public or Government owned learning institutions. However, beginning from the 1980s, higher education throughout the world started facing huge challenges ranging from economic, political, and social challenges. Olum (2002) observed that strategic planning in the public sector is a phenomenon of the early 1980s, significantly later than its development in the private sector. For instance, there were problems of competition over markets, access to funding and so forth. As a result, there was a growing demand to encompass strategic planning method in public Higher Education Institutions (HEIs) as a way of overcoming these challenges.

Nevertheless, despite the demand to develop strategic plans, most public HEIs in Zambia have not taken planning seriously. For example, MUCE has never developed an institutional strategic plan since its inception as a secondary teacher training college in 2008. At the moment the only existing plan is the plan of action developed for Open and Distance Learning for the period 2011-2012. Otherwise, neither institutional nor departmental plans are available at the institution. Because of this, departments at MUCE have found it very difficult to operate efficiently and effectively. This is indeed a big challenge as it entails that departments are operating without proper focus or directions and targets. For instance, there is no emphasis at institution level and let alone departmental level on the number and quality of students 'grades. Heads of Departments do not inspire their departments to meet intended targets for their departments because there are no 'targets' to be achieved in the first place.

Thus, the significance of this research is that when it is fully concluded, it will assist other government or public institutions to develop strategic plans, a practice which is not popular in Zambia yet.

\subsection{Problem Definition and Demarcation}

The Mathematics department at MUCE is operating without a formal strategic plan. Despite this, no serious attempts are being made to develop a departmental strategic plan at the college because the college and the Mathematics department in particular have never explored the benefits of developing a departmental strategic plan. As a consequence, the department faces a lot of challenges which includes:

- Enrolment

- Achieving institutional and departmental goals

- Satisfaction of the market in terms of relevance of the programmes and skills

- Conducive classroom space

- Assessment

- Teaching /learning materials

- Quality assurance

Thus, the absence of a formal Mathematics departmental strategic plan offers an opportunity for the researcher to conduct this study. At the same time it poses a seriously challenge to the researcher to come up with a solution plan; the draft departmental strategic plan for Mathematics department at MUCE.

\subsection{Research Questions}

1.4.1 Is there need for the mathematics department at MUCE to engage in strategic planning?

1.4.2 Why has the mathematics department at MUCE unable to develop a strategic plan?

1.4.3 What components of a strategic plan will be ideal for the mathematics department's strategic plan at MUCE?

1.4.4 How can the mathematics department at MUCE implement and enhance strategic planning?

\subsection{Describe Relevant Scholarship}

\subsubsection{Introduction}

This chapter was aimed at establishing the background to strategic planning and its eventual penetration into the education system. Both theoretical and practical exploration were thoroughly conducted in order to appreciate the challenges higher education has experienced before, during and after the introduction of strategic planning in HEIs around the world. This eventually provided a theoretical basis from which the Mathematics departmental strategic plan at MUCE was development. 


\subsection{Definition of Strategic Planning}

Planning and strategic planning in particular, have become critical issues for $21^{\text {st }}$ century managers; whether in private or public institutions. This is because most institutions nowadays are result or performance based. As such managers are working towards accomplishing institutions' set goals. Therefore, to attain this, they need to engage in serious planning. This is because effective planning gives direction to any activity being undertaken. Apart from that it makes managers to remain focused on the set objectives. According to Albanese (1975), planning is "the process of defining in advance specifically what needs to be done in order to achieve certain goals, how it should be done, when and where it should be done, and who should do it". This definition is self- contained as it takes care or addresses the four most important elements of planning: That is the barriers to achieving the goals, the ways or methods available to eliminating the barriers, the suitable time to implement the action and the place to carry out the action and eventually the people to execute the plan so as to be successful. Therefore, educational planning can be defined as a deliberate and continuous process of making decisions that influence the future direction of education. Hence, from the foregoing discussion, it can be concluded that, planning in education is very cardinal and that it should not be left to chance. Consequently, people tasked to execute these duties must take time to plan carefully in order to achieve intended results. With this background therefore, we now turn our attention to strategic planning, the main focus of this study.

While planning is a broad term, strategic planning is specific. It is about how institutions position themselves in order to achieve the set goals or targets in a broader market. It's about remaining focused as you look into the future. This means that, people charged with managing the welfare of companies or businesses must be prudent in the manner in which they manage and utilize companies' available resources. Several scholars on strategic planning have attested to this fact. For this reason, the study sampled some relevant definitions in order to bring this discussion into perspective. One of the definitions referred to in this study was that given by Hayward and Ncayiyana (2003), who defined strategic planning as "a conscious process by which an institution assess its current state and the likely future condition of its environment, identifies possible future states for itself, and then develops organized strategies, policies, and procedures for selecting and getting to one or more of them". On the other hand Barry (1997) added that, strategic planning was what an organization intended to achieve and, how leadership within an organization will direct or utilize its resources to achieve its ends. Finally, Shirley (1988) looked at strategic planning as a type of process that focuses on a melding of external opportunities and trends, internal strengths and weaknesses, and personal values of staff and community. Thus, it can be inferred from the foregoing definitions that, strategic planning required that institutions conduct an assessment or regular assessments of the business environment and prescribe objectives to be achieved in a foreseeable future. Therefore, strategic planning requires that leadership in these institutions and more so, Higher Educational Institutions (HEIs) remain disciplined and focused to make fundamental decisions and engage in actions that will shape the nature and direction of an organization's activities within legal parameters. Taylor, in agreeing to this, contended that, strategic planning was a tool for assisting an HEI manages itself with foresight and an external focus.

Hence, from the definitions given above, it can be concluded that, strategic planning is a way of assisting institutions to manage themselves with foresight. It's a tool that helps institutions scan their current environments in order to position themselves well to face and overcome the challenges in the internal as well as external environment in the near future. It involves human and physical resources and managers as drivers. Kathleen (2003) observed that, "through strategic planning, resources are concentrated in a limited number of major directions in order to maximize benefits to stakeholders ... those we exist to serve and who are affected by the choices we make". In short strategic planning guides the institution in its everyday dealing. It's a mirror through which an institution evaluates itself and that of competitors. Cope states that, "the essence of strategic planning is effectively relating the institution to its environment to ensure success."Therefore, institutions that engage in strategic planning are better organized than the ones which are not.

Thus, it is for this reason that there was a paradigm shift in the theories of management of public HEIs worldwide in the second half of the $20^{\text {th }}$ century. The dominant theories that emerged during this time emphasized modern methods of management systems which embraced strategic planning as one of the ways to improve organization's performance. Therefore, before we look at the benefits or importance of strategic planning to public HEIs, its necessary that we briefly trace the history of strategic planning.

\subsection{Theoretical Exploration}

\subsubsection{History of Strategic Planning in Higher Education Institutions (HEIs)}

The idea of strategic planning can be traced from the military. This was because of the idea of strategy which was used quite often in military operations. Dooris (2004) contended that, "strategic planning's roots are in the arena of large scale -military operations". As a result of this background, early models of formal strategic planning reflect the hierarchical values and linear systems of traditional organizations which were characterized by an elite planning 
function at the top of the organization.

However, beginning in the late 1950s, the concept of strategic planning began to spread and to attract interest from private organizations in America. By the mid-1960s and throughout the 1970s, strategic planning had become a common feature in most large private businesses or organizations in America and Europe. However, it was not until the late 1970s that strategic planning came to be recognized in public and Non-profit making organizations. Nezahat argues that "since the late 1970s, strategic planning has become the most widely advocated approach for institutions of higher education". From the preceding discussion, it can be said that, the idea of being strategic which was gotten from the military sense was transformed into a business idea; strategic planning business corporations in the private sector. Now as time unfolds, the idea of strategic planning began to occupy a central role in the management of public Higher Education Institutions and Non-profit making organizations globally. This change of scene can be attributed to several challenges facing managers of HEIs in the $21^{\text {st }}$ century as discussed below.

1.7.2 Factors that Prompted the Emphasis on Strategic Planning in Public HEIs.

Strategic planning was never part of public institutions before the second half of the $20^{\text {th }}$ century. This was because governments used to do most of the things these institutions needed. For example, public institutions were adequately funded and market for their products was readily available. These institutions faced less competition due to government protection. However, with the dawn of the 1950s, the situation started changing such that strategic planning became a life line for survival. Thus, the idea of strategic planning emerged out of the context to respond to the challenges facing higher education. Some of the challenges which affected public higher education worldwide are given below:

\subsubsection{Lack of clear vision and mission In most HEIs}

1.7.2.2 HEIs experienced a turbulent environment: that is school enrolment decreased, unpredictable government policies and emergence of new and advanced technologies in education.

\subsubsection{Increased competition among Institutions of Higher Learning}

1.7.2.4 Lack of consensus in public institutions regarding access, affordability and quality of education

1.7.2.5 Decreasing funding to public higher institutions of learning especially in developing countries, leading to professions leaving the teaching profession to go and seek employment elsewhere.

Rowley, Lujan \& Dolence (1997) attest to this when they stated that:

During the past decade, institutions of higher education had to confront numerous challenges in their external environment, and respond to emerging challenges such as decreasing financial support, rapid technological advances, changing demographics and outdated academic programmes.

Newman \& Couturier (2002) add that market forces, driven by the threat of competition have led to the emergence of higher education as a business.

\subsubsection{Benefits of Strategic Planning to HEIs}

Some scholars, (Bryson, 1998; Hayward \& Ncayiyana, 2003) for strategic planning have brought out benefits of effective strategic planning to an organization being it private, public or non- profit making. Some of these are highlighted below:

1.7.3.1 Strategic planning enables an organization to be proactive and to actively shape its own destiny. This is because the process pays attention to trends and external development.

1.7.3.2 Strategic planning leads to improved performance toward meeting the organization's mission statement.

1.7.3.3 Strategic planning usually leads to improved performance toward increasing the academic standing of the institution.

1.7.3.4 Furthermore, effective strategic planning increases accomplishments with the same or lower level of resources.

1.7.3.5 Strategic planning assists in clarifying the future direction of the institution.

1.7.3.6 Strategic planning helps organizations meet the requirements of accreditation of a government agency.

1.7.3.7 Strategic planning assist institutions solve major problems (threats) or address significant opportunities facing them.

1.7.3.8 Strategic planning helps to bring the institution or organization community together in a cooperative effort.

1.7.3.9 Strategic planning grants stability to the organization in spite of increasingly frequent leadership changes.

To support what has been mentioned above concerning the benefits of strategic planning Lawlor argued that, “... strategic planning provides a company purpose and direction... Without strategic planning, businesses simply drift, and 
are always reacting to the pressure of the day". On the other hand, Bryson (1988) observed that, "strategic planning gives the university, the college, the department and the administrative unit the opportunity to chart its own course and to focus its own future".

\subsection{Practical Exploration}

Strategic planning is one of the tools public institutions in Zambia are being encouraged to embark on. This is because of beneficial results that come along with it as already pointed out.

\subsubsection{Strategic Planning from the Ministry of Education}

MESVTEE, as a regulator of education in Zambia, has taken a leading role in strategic planning. This has been to stimulate interest of both private and public educational providers to engage in meaningful planning. To this effect, MESVTEE developed a strategic plan for 2003-2007. This document was developed from Educating Our Future, a policy document (1996), Poverty Reduction Strategy Paper (2001/2002), and the Report on the Restructuring and Decentralization of the Ministry of Education (2000). The documents addressed essential areas such as Access/ Equity, Quality, Financing, Administration and Management and HIV/ AIDS. Table 1 below gives a summary of the strategic goals of MESVTEE regarding Teacher Education and Higher Education.

Table 1. Sample of the MESVTEE Strategic Plan 2003-2007

\begin{tabular}{|c|c|c|}
\hline THEME & WORKING PROGRAMMERS & SUB-SECTOR GOAL \\
\hline \multirow[t]{6}{*}{ Access/ Equity } & Policy \& planning & Increase access to colleges of education \\
\hline & Financial Management & and universities through formal and distance modes, \\
\hline & Procurement & particularly for those with special education needs, women, and \\
\hline & Infrastructure & Vulnerable groups, \\
\hline & & Improve production of professionally competent teachers for the \\
\hline & Distance Education & new curricula in \\
\hline \multirow[t]{4}{*}{ Quality } & Teacher Education & $\begin{array}{l}\text { co- ordination with UNZA, private institutions and other line } \\
\text { Ministries }\end{array}$ \\
\hline & Curriculum \& Assessment & $\begin{array}{l}\text { Provide a high quality university education system, which will } \\
\text { produce skilled, }\end{array}$ \\
\hline & Standards \& Evaluation & $\begin{array}{l}\text { productive and socially responsible human resources for the } \\
\text { changing needs of the country }\end{array}$ \\
\hline & University & \\
\hline \multirow[t]{2}{*}{ Administration, } & Policy and Planning & $\begin{array}{l}\text { Strengthen the capacity of the College Educational Boards to } \\
\text { plan, cost, manage and }\end{array}$ \\
\hline & Human Resource and & monitor the delivery of quality teacher education. Develop a well \\
\hline Finance & Administration. & - managed university \\
\hline \multirow[t]{2}{*}{ Management } & Institutional Development & $\begin{array}{l}\text { system in terms of sound administration, financial planning and } \\
\text { cost - recovery. }\end{array}$ \\
\hline & university. & \\
\hline HIV/ AIDS & Policy \& planning, special issues & $\begin{array}{l}\text { Develop and support actions aimed at mitigating the impact of } \\
\text { HIV/AIDS on colleges and universities }\end{array}$ \\
\hline
\end{tabular}

The ministry's strategic plan as shown above plays an important role in the operations of public institutions. Whatever activities that take place in public institutions have a genesis from the MESVTEE strategic plan. So, in line with this, it is expected that, the MESVTEE strategic plan will influence the operations of teacher education colleges. For instance, if the Ministry wants to address the problems of access to quality education it will depend on schools, colleges and universities to implement this on its behalf. This means that MESVTEE will work with schools, colleges and universities to design the tuition fee structure, enrolment by gender and so forth.

\subsubsection{Strategic planning in Higher Education Institutions (Public Universities)}

Strategic planning by the two oldest public institutions: The University of Zambia (UNZA) and the Copperbelt University (CBU) has been an old practice although it gained momentum in the early 2000s. For instance, CBU has a strategic plan for 2009-2013 while UNZA has a Strategic Plan for 2013-2017.

At Copperbelt College of Education (Mukuba University), data has shown that the only written strategic plan in place was done for 2008-2011. Since the expiry of this plan no other strategic plan has been put in place. In short Mukuba University is operating without a formal strategic plan or it is operating under the 2008-2011 strategic plan. 


\subsubsection{Strategic Planning at (MUCE)}

While strategic planning has been a practice in some public higher institutions in Zambia as we have seen, this however, has not been the case in colleges of education, MUCE being one of them. At MUCE there has never been a written strategic plan since its inception as a secondary teacher training college in 2008. As a result of this, departmental strategic plans have not been implemented at the college. So, as this study is being undertaken, there is no formal strategic plan for both the institution and the Mathematics department in particular. However, this does not mean to suggest that the college has not been engaged in any form of planning, by far. The college has been planning its activities except the type of planning has been annual planning which to some extent can be called strategic planning. This planning is done at provincial level by all government departments. However, despite MUCE not having an institutional strategic plan, the department of Open and Distance Learning (ODL) developed an action plan for 20082011. Other than this, there is no any other written plan for the college and Mathematics department in particular.

\subsection{Theoretical Exploration}

\subsubsection{Relevant Model for the Study}

An extensive exploratory survey was conducted on various models on strategic planning. Some of the models looked at include the following: Five Forces and Value chain by Michael Porter, The stakeholders Analysis model, Ansoff's Matrix model and Strategic Planning Process Model by Bryson. Having scrutinized the models mentioned above, the researcher settled for the Strategic Planning Process Model. The researcher settled for this model because it's suitable and applicable to education. Apart from this, the model has six well- articulated and relevant elements required for the research at hand. The six important characteristics of the Strategic Planning Process Model are: Environmental Analysis, Resource Analysis, Goal Formulation, Strategic formulation, Organizational design and System design. Each of this part plays a significant role to the whole process of strategic planning. For instance, environmental analysis assisted the research in SWOT and PESTEL analysis of the environment where Mufulira College of Education is operating and saw how this influences the college's ability to engage into strategic planning. SWOT refers to Strengths, Weaknesses, Opportunities and Threats while PESTEL means Political, Economic, Sociological, Technological, and Environmental. The strengths and weaknesses refer to the prevailing conditions within MUCE such as infrastructure and the quality human resource in the institution. Opportunities and Threats refer to the pressures coming into the institution from the external environment; that is Government policies, donor funds, labour market and so forth. On the other hand, PESTEL looked at a big picture, the macro environment. This was cardinal as it unveiled more about the political stability of the environment, the strength of economic environment and the social aspects of it. The technological aspect helped to appreciate the influence of new technologies in education and in the environment as whole. So, carrying out these two analyses significantly assisted the study at hand.

Furthermore, the resource analysis played an important part in assisting the study to evaluate the extent to which the college staff, incomes (funds) infrastructure and other relevant systems within the institution help support the college to manage the programmes as expected by the government and other stakeholders or to the contrary impeded the college from delivering the programmes as expected by stakeholders.

The goal formulation part helped the researcher understood why the institution existed and what type of institution it is. That is the mission provided direction to scrutinize whether the institution is a service organization or a profit making institution.

In strategy formulation stage the researcher was assisted to understand the objectives at MUCE which are helping the institution market itself and its products on the market: To understand how MUCE was taking advantage of the prevailing business environment in Zambia and in the region to market its self and the products in order to gain an advantage over other institutions in the region?

Further still, the model helped to understand the organizational design of MUCE in terms of information flow or communication, organizational culture; how workers at MUCE react to change and how their attitude towards work is, and so forth. A good analysis of this stage assisted the researcher establish for instance, if the workers at MUCE are goal achievers and so on.

Finally the system design stage helped the study to come up with interventions in terms of planning and control.

For the reasons explained above, Bryson's model was much more appropriate for the research at hand.

\section{Research Design}

\subsection{Introduction}

The purpose of this chapter was to try and highlight what kind of steps would be necessary to arrive at the solution plan. Therefore, it's important that the required activities relevant to the solution be outlined nicely. In this project the 
activities to be considered included interviews (structured and unstructured), questionnaires and the SWOT and PESTEL analysis. In addition, elements of a strategic plan will be outlined.

\subsection{Solution Plan}

The solution plan was about developing a draft strategic plan for the Mathematics department at MUCE. In order to achieve this, the following activities were undertaken.

2.2.1 Interviews (semi- structured and structured) with members of the Mathematics department

and students of Mathematics and the client organization, which is MUCE

2.2.2 Questionnaires for the stake holders like the University of Zambia, Cooperating partners and others were administered

2.2.3 SWOT and PESTEL analysis was conducted.

The SWOT and PESTEL analyses were cardinal to this project in that they provided an insight as to what is really happening at the college and also to alert us to what challenges: threats and opportunities the college needs to be aware of. In case of SWOT analysis for instance, the college vision and mission was looked at to see how they are inspiring the department to engage in strategic planning. Also the issues on access, affordability and quality were very important in our SWOT analysis. This is because issues to do with access, affordability and quality have become key determinants of government and donor support. Furthermore, the issue of scarcity or dwindling of government and donor funds to education as stated in element six was very important to the SWOT and PESTEL analysis for this research. This helped the researcher to investigate how Mathematics department was able to use the existing opportunities to generate income for itself and the institution. The fact that MUCE is operating in a very competitive environment must bring out the entrepreneurial skills and help the Mathematics department to compete favourably. This is because the Zambian government has opened up the education system such that there so many education providers. These include private and public as well as international and local educational providers. This implies that competition has become stiff and therefore institutions such as MUCE who are government owned should wake up and start looking at education as a business. Thus, with the help of both PESTEL and SWOT, the researcher was assisted to understand the environment in which MUCE is operating and saw the threats and opportunities which are available for the Mathematics department at MUCE.

2.3 The elements of the mathematics departmental plan considered were:

2.3.1 Mission, Vision \& Values

2.3.2 Collaborators \& Beneficiaries

2.3.3 Environmental Scan

2.3.4 Goals

2.3.5 Strategies and Action plans

2.3.6 Plan Creation

2.3.7 Outcomes and Achievements.

2.4 Brief over View of Structure of the Paper

This research is divided into four chapters. Chapter one is the introductory part which aims to give a brief insight or the aims/or objectives of the research as well as the problem statement. A part from this, this chapter also looks at a brief structure of the client organization. Furthermore, this chapter will explore the literature around the topic at hand. To this effect, a thorough theoretical and practical exploration of the problem will be conducted in order to formulate concepts around the study. Chapter two is about the research design. It looks at how a solution plan will be achieved by discussing different approaches to the problem. It will guide the research by highlighting the activities that will lead to the solution plan which in this case is developing a mathematics strategic plan. Chapter three of the study will deal with the research methods. In this chapter, the researcher will develop research questions to assist him come up with a good solution plan. Research design data collection instruments will also be addressed in this chapter. Chapter four will discuss the research findings or results in relation to the four research questions. Conclusions and recommendations will also be discussed in this chapter.

\section{Method}

\subsection{Introduction}

This chapter as it is indicated will look at five sub-titles; namely research questions, research design, sampling techniques, data collection plan and data analysis plan. Each of these sub-titles will be elaborated further, 


\subsection{Research Questions}

3.2.1 Is there need for the mathematics department at MUCE to engage in strategic planning?

3.2.2 Why has the mathematics department at MUCE unable to develop a strategic plan?

3.2.3 What components of a strategic plan will be ideal for the mathematics department's strategic plan at MUCE?

3.2.4 How can the mathematics department at MUCE implement and enhance strategic planning?

3.3 Research Design

3.3.1 Population

$>$ Principal

All Mathematics Department Members of Staff

$>$ Twenty two randomly selected Mathematics students

$>$ Stakeholders interviews (MESTVEE, UNZA, Co-operating Partners)

$>$ Focus group: Three lecturers (for validation), eight students (two class representatives from each cohort)

3.3.2 Research Choice:Multi-method

3.3.3 Data Collection:

$>$ Exploratory /Survey (Ind. Interview: Semi-Structured questionnaire)

$>$ Desk research involving getting data from government reports, journals, books and internet sources.

$>$ Environmental scanning using SWOT and PESTEL Analysis

$>$ Cooperating partners

3.3.4 Time Horizon:- Cross-sectional

3.3.5 Strategy: - Survey

3.4 Sampling Techniques

No sampling will be used for the following:

3.4.1 Departmental Staff -6 lecturers

3.4.2 Principal /Client -1 , because the entire population will be used in respect of their small sizes.

Purposive sampling will be used for the following in order to get the most appropriate or relevant information.

3.4.3 Stakeholders - MESVTEE, UNZA, Co-operating Partners

However, for students: (Mathematics students), due to the large numbers/population, non-probabilistic sampling method will be used and a purposive sampling technique will be used to sample/select the $8 / 20$ students (i.e. class representatives)

\subsection{Data Collection Plan}

Interviews using a semi-structured interview guide and desk research will be used to collect data as follows:

RQ 1 - Desk Research

RQ 2 - the principal,

RQ 3 - Departmental Staff/Students: Interview

RQ 4 - Stakeholders (MESVTEE, UNZA, Cooperating partners)

\subsection{Data Analysis Plan}

Data collected was analyzed using Likert's 5 Scale model.

\section{Results}

\subsection{Introduction}

The purpose of this study was to investigate whether the Mathematics department at Mufulira College of Education (MUCE) uses strategic planning in its planning. In this chapter, findings from the study are presented and analysed in relation to the four (4) research questions. Discussions on these research questions were based on quantitative and qualitative analysis of data collected from questionnaires and interviews conducted with mathematics students and lecturers in the mathematics department at MUCE. In order to collect the needed data, five (5) mathematics lecturers 
and twenty two (22) pre-service mathematics student teachers that is, seven (7)students from each of First and Second year cohorts and eight (8) students from the Third year group were given questionnaires to complete. Students and lecturers responses from questionnaires were first presented in tables. These results were then subjected to further analysis using the Likert's 5 Scale model. The researcher was motivated to use this method because of the nature of the study; qualitative study.

The four research questions which the study aimed at answering are stated below:

$>$ Is there need for the mathematics department at MUCE to engage in strategic planning?

$>$ Why has the mathematics department at MUCE unable to develop a strategic plan?

$>$ What components of a strategic plan will be ideal for the mathematics department‘s strategic plan at MUCE?

How can the mathematics department at MUCE implement and enhance strategic planning?

Thus, in our discussion of the findings of the research, we will focus our attention on how each of the four questions has been adequately answered by the respondents.

\subsection{Findings}

Table 2 and table 3 below, illustrate how students and lecturers responded to question 1 .

Table 2 Mathematics Students' Responses to question 1: Is there need for the mathematics department at MUCE to engage in strategic planning?

\begin{tabular}{|c|c|c|c|c|c|c|}
\hline S/No & Statement & $\begin{array}{c}\text { Strongly } \\
\text { Agree }\end{array}$ & Agree & Uncertain & Disagree & $\begin{array}{l}\text { Strongly } \\
\text { Disagree }\end{array}$ \\
\hline $\mathrm{i}$ & Mathematics department is poorly organized & 2 & 3 & 1 & 7 & 9 \\
\hline ii & The vision of the department has lost its value. & 0 & 1 & 0 & 5 & 15 \\
\hline iii & $\begin{array}{l}\text { The mission statement of the department is no } \\
\text { longer applicable to the prevailing business } \\
\text { environment in the country. }\end{array}$ & 0 & 2 & 5 & 5 & 8 \\
\hline iv & $\begin{array}{l}\text { Students' activities in terms of assessment are } \\
\text { not systematically planned }\end{array}$ & 3 & 3 & 3 & 8 & 5 \\
\hline $\mathrm{v}$ & $\begin{array}{l}\text { Student records are poorly documented and } \\
\text { kept by the department. }\end{array}$ & 2 & 1 & 3 & 9 & 7 \\
\hline vi & $\begin{array}{l}\text { Students' assessments are rarely marked and } \\
\text { feedback not given in good time. }\end{array}$ & 0 & 3 & 5 & 11 & 3 \\
\hline vii & $\begin{array}{l}\text { Communication between the department and } \\
\text { its students is very poor }\end{array}$ & 1 & 1 & 1 & 8 & 10 \\
\hline viii & $\begin{array}{l}\text { The whole mathematics programme is not } \\
\text { well managed }\end{array}$ & 1 & 1 & 0 & 9 & 11 \\
\hline ix & $\begin{array}{l}\text { The department is over burdened with work } \\
\text { and therefore fails to deliver to the expectation } \\
\text { of the students }\end{array}$ & 4 & 4 & 2 & 8 & 4 \\
\hline
\end{tabular}

From the raw data illustrated in table 2, students' responses indicate that, the mathematics department is a wellorganized department. This is acknowledged from the students' responses to statements (i), (iv), (v), (vi), (viii) and (ix). Furthermore, students' responses also demonstrated that, communication between students and members of the mathematics department is cordial which can be attributed to good planning. In addition, students also argued that mathematics lecturers are not overburdened for them to fail to plan. To this effect, it can be inferred from students' responses that the mathematics department at MUCE plans its activities although this kind of planning may not be equivalent to strategic planning. 
Table 3 Mathematics lecturers' Responses to question 1: Is there need for the mathematics department at MUCE to engage in strategic planning?

\begin{tabular}{|c|c|c|c|c|c|c|}
\hline S/No & Statement & $\begin{array}{c}\text { Strongly } \\
\text { Agree }\end{array}$ & Agree & Uncertain & Disagree & $\begin{array}{l}\text { Strongly } \\
\text { Disagree }\end{array}$ \\
\hline $\mathrm{i}$ & $\begin{array}{l}\text { My department plans its activities before the } \\
\text { beginning of each new term }\end{array}$ & 2 & 2 & 0 & 0 & 0 \\
\hline ii & $\begin{array}{l}\text { Every member of the department is involved in } \\
\text { any departmental planning }\end{array}$ & 1 & 3 & 0 & 0 & 0 \\
\hline iii & $\begin{array}{l}\text { This planning has helped the department to be } \\
\text { focused throughout the year }\end{array}$ & 1 & 2 & 1 & 0 & 0 \\
\hline iv & $\begin{array}{l}\text { The department carefully plans students' activities } \\
\text { before the beginning of each term and this outline } \\
\text { of activities is given to students in good time }\end{array}$ & 1 & 2 & 1 & 0 & 0 \\
\hline $\mathrm{v}$ & $\begin{array}{l}\text { The department's students' record keeping and } \\
\text { documentation is excellent }\end{array}$ & 1 & 2 & 1 & 0 & 0 \\
\hline vi & $\begin{array}{l}\text { Lecturers mark tests/projects and feedback is given } \\
\text { to pupils in good time }\end{array}$ & 0 & 3 & 0 & 1 & 0 \\
\hline vii & $\begin{array}{l}\text { The lecturers in the department have empathy for } \\
\text { the students and try hard to assist vulnerable } \\
\text { students }\end{array}$ & 2 & 1 & 1 & 0 & 0 \\
\hline viii & $\begin{array}{l}\text { The department publicizes students' examinations } \\
\text { (promotion and diploma) as scheduled }\end{array}$ & 2 & 2 & 0 & 0 & 0 \\
\hline ix & $\begin{array}{l}\text { Lecturers in the department work as a team and } \\
\text { are goal achievers }\end{array}$ & 2 & 2 & 0 & 0 & 0 \\
\hline $\mathrm{x}$ & $\begin{array}{l}\text { The department successfully manages to } \\
\text { atisfactorily deliver the given programme } \\
\text { for the term or year to the students }\end{array}$ & 1 & 3 & 0 & 0 & 0 \\
\hline $\mathrm{xi}$ & $\begin{array}{l}\text { The department is over burdened with work and the } \\
\text { therefore has no time to plan its activities properly }\end{array}$ & 1 & 0 & 1 & 1 & 0 \\
\hline xii & $\begin{array}{l}\text { The planning that the department is currently } \\
\text { undertaking is the same as strategic planning }\end{array}$ & 1 & 2 & 1 & 0 & 0 \\
\hline
\end{tabular}

Table 3 on the other hand, illustrates lecturers' responses to question 1. From table 3 above, it is clearly demonstrated that the mathematics department is organized and plans its activities well. Statements (i), (iii) and (x) attest to this. Lecturers' responses further indicated that all members of the department are involved in the planning and that student activities are planned beforehand. Again this is demonstrated by the responses to statements (ii), (iv), (v), (vi), (iiiv), (ix) and $(\mathrm{x})$.

From the responses from the two groups of respondents, it can be concluded that, although there are somewhat differences between students' and lecturers' responses, on this question, data collected generally suggest that the mathematics department plans its activities even though there is no conclusive evidence as to whether the kind of planning of the mathematics department is equivalent to strategic planning. As a result of this, all the statements given in question 1 are not significant factors affecting the use of strategic planning for the mathematics department at MUCE. However, to have conclusive answers, these results were subjected to further analysis. 
Table 4 Mathematics Students' Responses to question 2: Why has the mathematics department at MUCE unable to develop a strategic plan?

\begin{tabular}{|c|c|c|c|c|c|c|}
\hline S/No & Statement & $\begin{array}{l}\text { Strongly } \\
\text { Agree }\end{array}$ & Agree & Uncertain & Disagree & $\begin{array}{l}\text { Strongly } \\
\text { Disagree }\end{array}$ \\
\hline $\mathrm{i}$ & Lecturers in the department are overstretched & 4 & 7 & 5 & 4 & 1 \\
\hline ii & $\begin{array}{l}\text { The college has a very good reputation because } \\
\text { of the quality of teachers produced }\end{array}$ & 11 & 6 & 2 & 1 & 2 \\
\hline $\mathrm{iii}$ & $\begin{array}{l}\text { Teachers of Mathematics produced at MUCE } \\
\text { readily find employment }\end{array}$ & 8 & 9 & 3 & 0 & 1 \\
\hline iv & $\begin{array}{l}\text { The college administration is skeptical about } \\
\text { strategic planning and therefore does not } \\
\text { motivate the mathematics department to } \\
\text { develop one. }\end{array}$ & 2 & 2 & 6 & 9 & 3 \\
\hline $\mathrm{v}$ & $\begin{array}{l}\text { The department is not united and lecturers } \\
\text { prefer to work individually }\end{array}$ & 2 & 1 & 1 & 6 & 12 \\
\hline vi & $\begin{array}{l}\text { e department lack capacity (has no trained } \\
\text { personnel) to engage in strategic planning }\end{array}$ & 0 & 0 & 1 & 8 & 13 \\
\hline vii & $\begin{array}{l}\text { The department does not see the benefits of } \\
\text { strategic planning }\end{array}$ & 0 & 0 & 5 & 10 & 7 \\
\hline viii & $\begin{array}{l}\text { Because other department in the college are not } \\
\text { doing it }\end{array}$ & 0 & 0 & 7 & 8 & 7 \\
\hline ix & $\begin{array}{l}\text { It's not a common practice in public institutions } \\
\text { in Zambia }\end{array}$ & 3 & 1 & 6 & 8 & 4 \\
\hline
\end{tabular}

Table 4 above, shows students' responses on the question why the mathematics department at MUCE is unable to engage in strategic planning. According to students' responses, one of the reasons why the department has failed to embark on strategic planning is that members of staff from the mathematics department are over stretched; they rarely have time to rest because of too many programmes. In the same way, students attributed the inability of the department to engage in strategic planning to the good reputation of the college, and mathematics department in particular. The department produces high quality teachers of mathematics which make would be students of mathematics want to train at MUCE. Students further attributed lack of involvement of the mathematics department in strategic planning to employability of the teachers of mathematics produced at MUCE. Teachers of mathematics trained at MUCE easily find employment either in public or private schools. These results are demonstrated in the table above.

To the contrary, the students did not attribute failure by the department to engage in strategic planning to lack of unity in the department or not having trained staff to guide the process. Moreover, the students did not think that the inability of the department to engage in strategic planning was due to the fact that other departments in the college do not use this system or because it's not a common practice among public learning institutions in Zambia. The students could not also attribute inability to develop a strategic plan by the mathematics department to failure to appreciate the benefits of strategic planning. 
Table 5 Mathematics Lecturers' Responses to question 2: Why has the mathematics department at MUCE unable to develop a strategic plan?

\begin{tabular}{|c|c|c|c|c|c|c|}
\hline S/No & Statement & $\begin{array}{l}\text { Strongly } \\
\text { Agree }\end{array}$ & Agree & Uncertain & Disagree & $\begin{array}{l}\text { Strongly } \\
\text { Disagree }\end{array}$ \\
\hline $\mathrm{i}$ & $\begin{array}{l}\text { The department is already using strategic } \\
\text { planning in its planning }\end{array}$ & 0 & 2 & 2 & 0 & 0 \\
\hline ii & Its costly and time consuming & 0 & 3 & 0 & 1 & 0 \\
\hline iii & $\begin{array}{l}\text { The department has no competent staff to } \\
\text { develop a strategic plan }\end{array}$ & 0 & 1 & 1 & 1 & 1 \\
\hline iv & $\begin{array}{l}\text { No public college in Zambia is doing } \\
\text { strategic planning }\end{array}$ & 0 & 0 & 2 & 2 & 0 \\
\hline $\mathrm{v}$ & $\begin{array}{l}\text { The college administration does not } \\
\text { inspire the department to engage into this } \\
\text { type of planning }\end{array}$ & 0 & 0 & 3 & 1 & 0 \\
\hline vi & $\begin{array}{l}\text { The department has a good reputation } \\
\text { because of the teachers of mathematics } \\
\text { being produced at MUCE }\end{array}$ & 1 & 3 & 0 & 0 & 0 \\
\hline vii & $\begin{array}{l}\text { Teachers of mathematics produced at } \\
\text { MUCE readily find employment }\end{array}$ & 0 & 4 & 0 & 0 & 0 \\
\hline viii & $\begin{array}{l}\text { The department is not united and lecturers } \\
\text { prefer to work individually }\end{array}$ & 0 & 0 & 1 & 2 & 1 \\
\hline ix & $\begin{array}{l}\text { The department does not visualize the } \\
\text { benefits of strategic planning }\end{array}$ & 0 & 0 & 0 & 4 & 0 \\
\hline $\mathrm{x}$ & $\begin{array}{l}\text { The department is satisfied with the } \\
\text { current planning system }\end{array}$ & 0 & 1 & 2 & 0 & 0 \\
\hline $\mathrm{xi}$ & $\begin{array}{l}\text { There are no external and internal } \\
\text { factors prompting the department to } \\
\text { embark on strategic planning }\end{array}$ & 0 & 1 & 3 & 0 & 0 \\
\hline
\end{tabular}

Table 5 above, shows responses by members of the mathematics department to the question: Why the mathematics department at MUCE is unable to develop a strategic plan? The responses from the lecturers indicated that, all the listed statements were factors except one about lack of competent staff to develop the strategic plan.

Thus, from the foregoing discussion, it can be observed that there are a number of similarities in the response pattern of the two groups of respondents than there are differences. As a consequence the results were subjected to further analysis in order to obtain conclusive or to ascertain these results 
Table 6 Mathematics Students' Responses to question 3: What components of a strategic plan will be ideal for the mathematics department's strategic plan at MUCE?

\begin{tabular}{|c|c|c|c|c|c|c|}
\hline S/No & Statement & $\begin{array}{l}\text { Strongly } \\
\text { Agree }\end{array}$ & Agree & Uncertain & Disagree & $\begin{array}{l}\text { Strongly } \\
\text { Disagree }\end{array}$ \\
\hline $\mathrm{i}$ & $\begin{array}{l}\text { The department should consider } \\
\text { developing vision and mission statements } \\
\text { which will respond to the current free } \\
\text { market(liberalized) economy }\end{array}$ & 11 & 9 & 1 & 0 & 0 \\
\hline ii & $\begin{array}{l}\text { The department must always set } \\
\text { achievable goals for itself }\end{array}$ & 12 & 9 & 0 & 1 & 0 \\
\hline iii & $\begin{array}{l}\text { The department must design value } \\
\text { statements (work culture) for its academic } \\
\text { staff to enable it achieve the set objectives }\end{array}$ & 8 & 13 & 1 & 0 & 0 \\
\hline iv & $\begin{array}{l}\text { The department should include ways on } \\
\text { how to scan the environment in order to } \\
\text { appreciate the strengthens, weaknesses, } \\
\text { opportunities and threats }\end{array}$ & 7 & 11 & 1 & 0 & 0 \\
\hline $\mathrm{v}$ & $\begin{array}{l}\text { The department should consider including } \\
\text { labour related issues }\end{array}$ & 3 & 11 & 5 & 3 & 0 \\
\hline vi & $\begin{array}{l}\text { he department should consider including } \\
\text { ways of how to enhance the relationship } \\
\text { with its alumni (former students) }\end{array}$ & 6 & 10 & 4 & 2 & 0 \\
\hline vii & $\begin{array}{l}\text { The department should include elements } \\
\text { related to quality of its products } \\
\text { (teachers) }\end{array}$ & 9 & 12 & 1 & 0 & 0 \\
\hline
\end{tabular}

Table 6 above was meant to find out from students what elements of a strategic plan they think would be ideal or suitable for mathematics department at MUCE. Many of the students who took part in the study agreed to the stated statements although few of them showed doubts on certain statements. The students agreed with all the suggested elements by the researcher. For instance, students' responses on whether the ideal strategic plan should include setting of achievable goals, 21 students either strongly agreed or simply agreed, whereas 1 student disagreed. In a similar way, for the statement whether the department should include labour related issues, results indicated that, 14 students either strongly agreed or simply agreed, 3 disagreed and 5 indicated uncertain. Thus, while the general picture of students' responses to question 3 appears to be positive, this may not be a true picture. For this reason, further analysis of these responses will yield a more conclusive result. 
Table 7 Mathematics lecturers' Responses to question 3: What components of a strategic plan will be ideal for the mathematics department's strategic plan at MUCE?

\begin{tabular}{|c|c|c|c|c|c|c|}
\hline S/No & Statement & $\begin{array}{l}\text { Strongly } \\
\text { Agree }\end{array}$ & Agree & Uncertain & Disagree & $\begin{array}{l}\text { Strongly } \\
\text { Disagree }\end{array}$ \\
\hline $\mathrm{i}$ & $\begin{array}{l}\text { The department should develop a } \\
\text { mission statement }\end{array}$ & 0 & 1 & 2 & 1 & 0 \\
\hline ii & $\begin{array}{l}\text { The strategic plan should come up with } \\
\text { a vision of the mathematics department }\end{array}$ & 1 & 1 & 2 & 0 & 0 \\
\hline iii & $\begin{array}{l}\text { The strategic plan for the department } \\
\text { should clearly state achievable goals }\end{array}$ & 0 & 4 & 0 & 0 & 0 \\
\hline iv & $\begin{array}{l}\text { The departmental strategic plan should } \\
\text { outline values expected of the members } \\
\text { staff }\end{array}$ & 1 & 3 & 0 & 0 & 0 \\
\hline $\mathrm{v}$ & $\begin{array}{l}\text { The departmental strategic plan should } \\
\text { include elements of how to scan the } \\
\text { environment for Strengths, } \\
\text { Weaknesses, Opportunities and Threats }\end{array}$ & 0 & 4 & 0 & 0 & 0 \\
\hline vi & $\begin{array}{l}\text { The departmental strategic plan should } \\
\text { include labour issues }\end{array}$ & 1 & 2 & 1 & 0 & 0 \\
\hline vii & $\begin{array}{l}\text { The departmental strategic plan should } \\
\text { outline ways the mathematics } \\
\text { department would relate with its } \\
\text { alumni }\end{array}$ & 0 & 4 & 0 & 0 & 0 \\
\hline viii & $\begin{array}{l}\text { The departmental strategic plan should } \\
\text { highlight the quality of teachers of } \\
\text { mathematics to be produced at MUCE. }\end{array}$ & 1 & 3 & 0 & 0 & 0 \\
\hline
\end{tabular}

Unlike the students' responses above, lecturers' responses to question 3 indicated in table 7, showed similarities on all the statements given. To begin with, the lecturers agreed that the ideal strategic plan for the department should include achievable goals, values, elements related to environmental scanning, labour related issues, and ways of how to engage the alumni and also highlight quality features expected in a mathematics teacher produced by the department. However, the lecturers could not agree nor deny whether the mission statement should be changed so as to make it more meaningful to the prevailing business environment.

Looking at the two groups of respondents' response to question 3, we see that the lecturers and students seem to agree on the elements suitable for the mathematics department strategic plan although some students were not sure or did not understand what should be ideal for the strategic plan of the mathematics department. For this reason, further analyses of these raw data needed to be conducted to assist the researcher make informed decisions or conclusions. 
Table 8 Mathematics Students' Responses to Question 4: How can the mathematics department at MUCE implement and enhance strategic planning?

\begin{tabular}{|c|c|c|c|c|c|c|}
\hline S/No & Statement & $\begin{array}{c}\text { Strongly } \\
\text { Agree }\end{array}$ & Agree & Uncertain & Disagree & $\begin{array}{l}\text { Strongly } \\
\text { Disagree }\end{array}$ \\
\hline $\mathrm{i}$ & $\begin{array}{l}\text { The department should embark on } \\
\text { developing its strategic plan by learning } \\
\text { from other learning institutions that have } \\
\text { strategic plans }\end{array}$ & 16 & 6 & 0 & 0 & 0 \\
\hline ii & $\begin{array}{l}\text { The college administration should } \\
\text { encourage the department to engage in } \\
\text { strategic planning by funding strategic } \\
\text { planning activities. }\end{array}$ & 15 & 7 & 0 & 0 & 0 \\
\hline iii & $\begin{array}{l}\text { The department, through the college } \\
\text { administration should partner with other } \\
\text { stake holders in order to develop the } \\
\text { strategic plan }\end{array}$ & 13 & 7 & 2 & 0 & 0 \\
\hline iv & $\begin{array}{l}\text { The college should facilitate for training } \\
\text { of members of the department in strategic } \\
\text { planning }\end{array}$ & 9 & 12 & 1 & 0 & 0 \\
\hline $\mathrm{v}$ & $\begin{array}{l}\text { The department should scan the } \\
\text { environment in order to come up with the } \\
\text { right strategy }\end{array}$ & 11 & 9 & 1 & 1 & 0 \\
\hline vi & $\begin{array}{l}\text { The department should compare with } \\
\text { what other competing institutions are } \\
\text { doing }\end{array}$ & 9 & 12 & 0 & 0 & 1 \\
\hline vii & $\begin{array}{l}\text { The government should encourage and } \\
\text { support the department in its efforts to } \\
\text { develop strategic plans }\end{array}$ & 17 & 3 & 0 & 1 & 1 \\
\hline viii & $\begin{array}{l}\text { The mathematics department should } \\
\text { consider partnering with public } \\
\text { institutions such as the University of } \\
\text { Zambia and the Copperbelt } \\
\text { University already grounded in } \\
\text { strategic Planning in order a develop a } \\
\text { suitable plan }\end{array}$ & 19 & 2 & 1 & 0 & 0 \\
\hline
\end{tabular}

Table 8 represents response patterns of students to question 4. This question was meant to address the question of how to implement the strategic plan for the mathematics department at MUCE. According to the students' responses, it was agreed that the college administration should take interest in encouraging members of the department to develop the strategic plan and also to facilitate for their training in strategic planning. Furthermore, students felt that the government should engage the college and particularly the mathematics department in developing the departmental strategic plan by way of funding the process. In addition, students agreed to the fact that, the government should work with the college in sourcing for other stakeholders to assist the mathematics department develop the strategic plan. In a similar vein, the students also agreed to the suggestion that the mathematics department should partner with other public institutions such as the University of Zambia who have been developing strategic plans. From the foregoing discussion, it's important to acknowledge from the students' responses that, funding, commitment and support both from the college and government will be cardinal for the implementation of the strategic plan at MUCE. Alongside these, building partnership with learning institutions grounded in strategic planning as well as other stakeholders should not be overlooked. All in all, students agreed to all the stated statements for this question. 
Table 9 Mathematics Lecturers' Responses to Question 4: How can the mathematics department at MUCE implement and enhance strategic planning?

\begin{tabular}{|c|c|c|c|c|c|c|}
\hline S/No & Statement & $\begin{array}{l}\text { Strongly } \\
\text { Agree }\end{array}$ & Agree & Uncertain & Disagree & $\begin{array}{l}\text { Strongly } \\
\text { Disagree }\end{array}$ \\
\hline $\bar{i}$ & $\begin{array}{l}\text { The department should embark on developing its } \\
\text { strategic plan by learning from other learning } \\
\text { institutions (Private and public) that have strategic plans }\end{array}$ & 3 & 1 & 0 & 0 & 0 \\
\hline ii & $\begin{array}{l}\text { The college administration should encourage the } \\
\text { department to engage in strategic planning by funding } \\
\text { strategic planning activities }\end{array}$ & 2 & 2 & 0 & 0 & 0 \\
\hline iii & $\begin{array}{l}\text { The department, through the college administration } \\
\text { should partner with other stakeholders in order to } \\
\text { develop the strategic plan }\end{array}$ & 2 & 1 & 1 & 0 & 0 \\
\hline iv & $\begin{array}{l}\text { The college should facilitate for training of members of } \\
\text { mathematics in strategic planning }\end{array}$ & 2 & 2 & 0 & 0 & 0 \\
\hline $\mathrm{v}$ & $\begin{array}{l}\text { The department should scan the environment in order to } \\
\text { find out more on its Strengths, Weaknesses. } \\
\text { Opportunities and Threats }\end{array}$ & 1 & 3 & 0 & 0 & 0 \\
\hline vi & $\begin{array}{l}\text { The department should compare with what other } \\
\text { competing institutions are doing }\end{array}$ & 2 & 1 & 1 & 0 & 0 \\
\hline vii & $\begin{array}{l}\text { The government should encourage and support the } \\
\text { department in its efforts to develop strategic plans }\end{array}$ & 2 & 2 & 0 & 0 & 0 \\
\hline viii & $\begin{array}{l}\text { The mathematics department should consider partnering } \\
\text { with public institutions such as the University of } \\
\text { Zambia and the Copperbelt University already } \\
\text { grounded in strategic planning. }\end{array}$ & 3 & 1 & 0 & 0 & 0 \\
\hline
\end{tabular}

Table 9 above, demonstrates responses obtained from lecturers on question 4. According to the responses gathered, all the five lecturers agreed to the stated statements. For instance, the lecturers agreed to the statement which stated that, the department should compare with what other competing institutions are doing. Apart from this, lecturers also agreed that, the department should partner with other stakeholders in order to develop the strategic plan for the department.

Therefore, students and lecturers unanimously agreed that, if the strategic plan was to be implemented and enhanced by the department, then all the stated statements have to be taken serious.

From the foregoing discussion, it's very clear that not all the stated statements are factors to strategic planning. This is evidenced from responses given by the students and lecturers as outlined above. For this reason, the researcher subjected these statements to further scrutiny or analysis using the Likert's 5 Scale model as shown in the tables below.

\subsection{Discussion}

In order to perform a good analysis of the Likert's 5 scale model on the students and lecturers responses outlined above, the researcher decided to ignore the responses for the category uncertain because it does not provide enough support. This means that if one is uncertain about something, it is as good as someone who has not answered. Therefore, the researcher decided to work with extreme values, both to the left and right of the category uncertain. For this reason, the group average or mean is 2.5 , considering the scale: $4,3,2$ and 1 . This was compared with the average or mean obtained by the sum of each category divided by fifteen. For example 2.1 in table 10 , was obtained as follows:

$$
(2 \times 4)+(5 \times 3)+(1 \times 2)+(1 \times 7)=32 \text {. Then }
$$

Mean $=32 / 15$. (i) is not a factor since it is less than 2.5, the group average. This process was continued until the last statement as displayed in the preceding tables below.

Note: For this analysis, all values less than 2.5 were considered insignificant factors to the question at hand. 
Table 10 Analysis of mathematics students' response for question 1: Is there need for the mathematics department at MUCE to engage in strategic planning?

\begin{tabular}{|c|c|c|c|c|c|c|c|}
\hline S/No & Statement & $\begin{array}{l}\text { Strongly } \\
\text { Agree }\end{array}$ & Agree & Uncertain & Disagree & $\begin{array}{l}\text { Strongly } \\
\text { Disagree }\end{array}$ & Mean \\
\hline $\mathrm{i}$ & $\begin{array}{l}\text { Mathematics department is poorly } \\
\text { organized }\end{array}$ & 2 & 5 & 1 & 1 & 7 & 2.1 \\
\hline ii & $\begin{array}{l}\text { The vision of the department has lost } \\
\text { its value }\end{array}$ & 1 & 5 & 0 & 3 & 6 & 2.1 \\
\hline iii & $\begin{array}{l}\text { The mission statement of the } \\
\text { department is no longer applicable to } \\
\text { the prevailing business environment } \\
\text { in the country. }\end{array}$ & 2 & 4 & 5 & 9 & 0 & 2.5 \\
\hline iv & $\begin{array}{l}\text { Students' activities in terms of } \\
\text { assessment are not systematically } \\
\text { planned }\end{array}$ & 0 & 6 & 3 & 2 & 7 & 1.9 \\
\hline $\mathrm{v}$ & $\begin{array}{l}\text { Student records are poorly } \\
\text { documented and kept by the } \\
\text { department }\end{array}$ & 3 & 4 & 3 & 2 & 6 & 2.3 \\
\hline vi & $\begin{array}{l}\text { Student records are poorly } \\
\text { documented and kept by the } \\
\text { department }\end{array}$ & 2 & 5 & 5 & 0 & 8 & 2.1 \\
\hline vii & $\begin{array}{l}\text { Communication between the } \\
\text { department and its students is very } \\
\text { poor }\end{array}$ & 1 & 5 & 1 & 6 & 3 & 2.3 \\
\hline viii & $\begin{array}{l}\text { The whole mathematics programme } \\
\text { is not well managed }\end{array}$ & 0 & 5 & 0 & 1 & 9 & 1.7 \\
\hline ix & $\begin{array}{l}\text { The department is over burdened } \\
\text { with work and therefore fails to } \\
\text { deliver to the expectation of the } \\
\text { students }\end{array}$ & 3 & 4 & 2 & 5 & 3 & 2.5 \\
\hline
\end{tabular}

Table 10 above, demonstrated that, for question 1, statements (iii), and (ix) were the only significant factors to be considered for question 1 
Table 11 Analysis of mathematics lecturers' response for question $1:$ Is there need for the mathematics department at MUCE to engage in strategic planning?

\begin{tabular}{|c|c|c|c|c|c|c|c|}
\hline S/No & Statement & $\begin{array}{l}\text { Strongly } \\
\text { Agree }\end{array}$ & Agree & Uncertain & Disagree & $\begin{array}{l}\text { Strongly } \\
\text { Disagree }\end{array}$ & Mean \\
\hline $\mathrm{i}$ & $\begin{array}{l}\text { My department plans its activities before } \\
\text { the beginning of each new term }\end{array}$ & 8 & 1 & 0 & 4 & 2 & 3.0 \\
\hline ii & $\begin{array}{l}\text { Every member of the department is } \\
\text { involved in any departmental planning }\end{array}$ & 6 & 2 & 0 & 3 & 4 & 2.7 \\
\hline iii & $\begin{array}{l}\text { This planning has helped the department to } \\
\text { be focused throughout the year }\end{array}$ & 5 & 4 & 1 & 3 & 2 & 2.7 \\
\hline iv & $\begin{array}{l}\text { The department carefully plans students' } \\
\text { activities before the beginning of each } \\
\text { term and this outline of activities is given } \\
\text { to students in good time }\end{array}$ & 5 & 3 & 1 & 6 & 1 & 2.8 \\
\hline $\mathrm{v}$ & $\begin{array}{l}\text { The department's students' record keeping } \\
\text { and documentation is excellent }\end{array}$ & 7 & 1 & 1 & 5 & 2 & 2.9 \\
\hline vi & $\begin{array}{l}\text { Lecturers mark tests/projects and feedback } \\
\text { is given to pupils in good time }\end{array}$ & 2 & 7 & 0 & 5 & 1 & 2.7 \\
\hline vii & $\begin{array}{l}\text { The lecturers in the department have } \\
\text { empathy for the students and try hard to } \\
\text { assist vulnerable students }\end{array}$ & 6 & 3 & 1 & 4 & 2 & 2.9 \\
\hline viii & $\begin{array}{l}\text { The department publicizes students' } \\
\text { examinations (promotion and diploma) as } \\
\text { scheduled }\end{array}$ & 9 & 0 & 0 & 5 & 1 & 2.5 \\
\hline ix & $\begin{array}{l}\text { Lecturers in the department work as a team } \\
\text { and are goal achievers }\end{array}$ & 3 & 6 & 0 & 2 & 4 & 2.9 \\
\hline $\mathrm{x}$ & $\begin{array}{l}\text { The department successfully manages to } \\
\text { satisfactorily deliver the given programme } \\
\text { for the term or year to the students }\end{array}$ & 8 & 0 & 0 & 4 & 3 & 2.9 \\
\hline xi & $\begin{array}{l}\text { The department is over burdened with } \\
\text { work and the therefore has no time to plan } \\
\text { its activities properly }\end{array}$ & 0 & 7 & 1 & 2 & 6 & 2.1 \\
\hline xii & $\begin{array}{l}\text { The planning that the department is } \\
\text { currently undertaking is the same as } \\
\text { strategic planning }\end{array}$ & 5 & 4 & 1 & 0 & 6 & 2.5 \\
\hline
\end{tabular}


Table 12 Analysis of mathematics students' response for question 2: Why has the mathematics department at MUCE unable to develop a strategic plan?

\begin{tabular}{|c|c|c|c|c|c|c|c|}
\hline S/No & Statement & $\begin{array}{c}\text { Strongly } \\
\text { Agree }\end{array}$ & Agree & Uncertain & Disagree & $\begin{array}{l}\text { Strongly } \\
\text { Disagree }\end{array}$ & Mean \\
\hline $\mathrm{i}$ & $\begin{array}{l}\text { Lecturers in the department are } \\
\text { overstretched }\end{array}$ & 3 & 4 & 5 & 7 & 1 & 2.6 \\
\hline ii & $\begin{array}{l}\text { The college has a very good } \\
\text { reputation because of the quality of } \\
\text { teachers produced }\end{array}$ & 8 & 1 & 2 & 4 & 2 & 3.0 \\
\hline iii & $\begin{array}{l}\text { Teachers of Mathematics produced at } \\
\text { MUCE readily find employment }\end{array}$ & 7 & 2 & 3 & 5 & 1 & 3.0 \\
\hline iv & $\begin{array}{l}\text { The college administration is skeptical } \\
\text { about strategic planning and therefore } \\
\text { does not motivate the mathematics } \\
\text { department to develop one. }\end{array}$ & 5 & 4 & 6 & 0 & 6 & 2.5 \\
\hline $\mathrm{v}$ & $\begin{array}{l}\text { ie department is not united and lecturers } \\
\text { prefer to work individually }\end{array}$ & 2 & 4 & 1 & 3 & 6 & 2.1 \\
\hline vi & $\begin{array}{l}\text { The department lack capacity (has no } \\
\text { trained personnel) to engage in } \\
\text { strategic planning }\end{array}$ & 1 & 5 & 1 & 2 & 7 & 2.0 \\
\hline vii & $\begin{array}{l}\text { The department does not see the } \\
\text { benefits of strategic planning }\end{array}$ & 1 & 5 & 5 & 2 & 7 & 2.0 \\
\hline viii & $\begin{array}{l}\text { Because other department in the } \\
\text { college are not doing it }\end{array}$ & 0 & 6 & 7 & 8 & 1 & 2.3 \\
\hline ix & $\begin{array}{l}\text { It's not a common practice in public } \\
\text { institutions in Zambia }\end{array}$ & 3 & 4 & 6 & 2 & 6 & 2.3 \\
\hline
\end{tabular}

In table 12 the results obtained indicated that statements (iv), (v), (vi) and (vii) were insignificant factors. This implies that the department's inability to embark on strategic plan at MUCE cannot to a larger extent be attributed to the college administration's skepticism about strategic plan. In the same way lack of trained personnel and unity in the department as well as failure to appreciate the benefits that come with strategic planning are not factors that impact negatively on the department's zeal to engage in strategic planning.

Table 13 Analysis of mathematics lecturers' responses for question 2: Why has the mathematics department at MUCE unable to develop a strategic plan?

\begin{tabular}{|c|c|c|c|c|c|c|c|}
\hline S/No & Statement & $\begin{array}{l}\text { Strongly } \\
\text { Agree }\end{array}$ & Agree & Uncertain & Disagree & $\begin{array}{l}\text { Strongly } \\
\text { Disagree }\end{array}$ & Mean \\
\hline $\mathrm{i}$ & $\begin{array}{l}\text { The department is already using } \\
\text { strategic planning in its planning }\end{array}$ & 8 & 1 & 2 & 4 & 2 & 3.0 \\
\hline ii & Its costly and time consuming & 6 & 2 & 0 & 3 & 4 & 2.7 \\
\hline iii & $\begin{array}{l}\text { The department has no competent staff } \\
\text { to develop a strategic plan }\end{array}$ & 5 & 4 & 1 & 3 & 2 & 2.7 \\
\hline iv & $\begin{array}{l}\text { No public college in Zambia is doing } \\
\text { strategic planning }\end{array}$ & 5 & 3 & 2 & 6 & 1 & 2.8 \\
\hline $\mathrm{v}$ & $\begin{array}{l}\text { The college administration does not } \\
\text { inspire the department to engage into } \\
\text { this type of planning }\end{array}$ & 7 & 1 & 3 & 5 & 2 & 2.9 \\
\hline vi & $\begin{array}{l}\text { Ie department has a good reputation } \\
\text { because of the teachers of mathematics } \\
\text { being produced at MUCE }\end{array}$ & 2 & 7 & 0 & 5 & 1 & 2.7 \\
\hline vii & $\begin{array}{l}\text { Teachers of mathematics produced at } \\
\text { MUCE readily find employment }\end{array}$ & 6 & 3 & 0 & 4 & 2 & 2.9 \\
\hline viii & $\begin{array}{l}\text { he department is not united and } \\
\text { lecturers prefer to work individually }\end{array}$ & 9 & 0 & 1 & 5 & 1 & 2.5 \\
\hline ix & $\begin{array}{l}\text { The department does not visualize the } \\
\text { benefits of strategic planning }\end{array}$ & 3 & 6 & 0 & 2 & 4 & 2.9 \\
\hline
\end{tabular}




\begin{tabular}{|c|c|c|c|c|c|c|c|}
\hline $\mathrm{x}$ & $\begin{array}{l}\text { The department is satisfied with the } \\
\text { current planning system }\end{array}$ & 8 & 0 & 2 & 4 & 3 & 2.9 \\
\hline xi & $\begin{array}{l}\text { here are no external and internal factors } \\
\text { prompting the department } \\
\text { to embark on strategic planning }\end{array}$ & 2 & 5 & 3 & 1 & 7 & 2.1 \\
\hline
\end{tabular}

Table 14 Analysis of mathematics students' response for question 3: What components of a strategic plan will be ideal for the mathematics department's strategic plan at MUCE?

\begin{tabular}{|c|c|c|c|c|c|c|c|}
\hline S/No & Statement & $\begin{array}{l}\text { Strongly } \\
\text { Agree }\end{array}$ & Agree & Uncertain & Disagree & Strongly Disagree & Mean \\
\hline $\mathrm{i}$ & $\begin{array}{l}\text { The department should } \\
\text { consider developing vision } \\
\text { and mission statements which } \\
\text { will respond to the current } \\
\text { free market(liberalized) } \\
\text { economy }\end{array}$ & 8 & 0 & 1 & 3 & 4 & 2.8 \\
\hline ii & $\begin{array}{l}\text { The department must always } \\
\text { set achievable goals for itself }\end{array}$ & 8 & 1 & 0 & 4 & 2 & 3.0 \\
\hline iii & $\begin{array}{l}\text { The department must design } \\
\text { value statements (work } \\
\text { culture) for its academic staff } \\
\text { to enable it achieve the set } \\
\text { objectives }\end{array}$ & 7 & 1 & 1 & 4 & 3 & 2.8 \\
\hline iv & $\begin{array}{l}\text { The department should } \\
\text { include ways on how to scan } \\
\text { the environment in order to } \\
\text { appreciate the strengthens, } \\
\text { weaknesses, opportunities } \\
\text { and threats }\end{array}$ & 9 & 0 & 1 & 2 & 4 & 2.8 \\
\hline $\mathrm{v}$ & $\begin{array}{l}\text { The department should } \\
\text { consider including labour } \\
\text { related issues }\end{array}$ & 4 & 5 & 5 & 6 & 0 & 2.9 \\
\hline vi & $\begin{array}{l}\text { he department should consider } \\
\text { including ways of how to } \\
\text { enhance the relationship } \\
\text { with its alumni (former } \\
\text { students) }\end{array}$ & 5 & 3 & 4 & 1 & 6 & 2.5 \\
\hline vii & $\begin{array}{l}\text { The department should } \\
\text { include elements related to } \\
\text { quality of its products } \\
\text { (teachers) }\end{array}$ & 6 & 2 & 1 & 4 & 3 & 2.7 \\
\hline
\end{tabular}

Table 14 above shows that all the statements mentioned are factors to be considered. This is because the averages are all above 2.5; the group mean. 
Table 15 Analysis of mathematics lecturers' responses for question 3: What components of a strategic plan will be ideal for the mathematics department's strategic plan at MUCE?

\begin{tabular}{|c|c|c|c|c|c|c|c|}
\hline S/No & Statement & $\begin{array}{c}\text { Strongly } \\
\text { Agree }\end{array}$ & Agree & Uncertain & Disagree & $\begin{array}{l}\text { Strongly } \\
\text { Disagree }\end{array}$ & Mean \\
\hline $\mathrm{i}$ & $\begin{array}{l}\text { The department should develop a } \\
\text { mission statement }\end{array}$ & 7 & 2 & 2 & 5 & 1 & 3.0 \\
\hline ii & $\begin{array}{l}\text { The strategic plan should come up } \\
\text { with a vision of the mathematics } \\
\text { department }\end{array}$ & 8 & 0 & 2 & 4 & 3 & 2.9 \\
\hline iii & $\begin{array}{l}\text { The strategic plan for the department } \\
\text { should clearly state achievable goals }\end{array}$ & 6 & 3 & 0 & 4 & 2 & 2.9 \\
\hline iv & $\begin{array}{l}\text { The departmental strategic plan } \\
\text { should outline values expected of the } \\
\text { members staff }\end{array}$ & 5 & 3 & 0 & 6 & 1 & 2.8 \\
\hline $\mathrm{v}$ & $\begin{array}{l}\text { The departmental strategic plan } \\
\text { should include elements of how to } \\
\text { scan the environment for Strengths, } \\
\text { Weaknesses, Opportunities and } \\
\text { Threats }\end{array}$ & 7 & 2 & 0 & 5 & 1 & 3.0 \\
\hline vi & $\begin{array}{l}\text { The departmental strategic plan } \\
\text { should include labour issues }\end{array}$ & 3 & 5 & 1 & 0 & 7 & 2.3 \\
\hline vii & $\begin{array}{l}\text { The departmental strategic plan } \\
\text { should outline ways the mathematics } \\
\text { department would relate with its } \\
\text { alumni }\end{array}$ & 5 & 4 & 0 & 1 & 5 & 2.6 \\
\hline viii & $\begin{array}{l}\text { The departmental strategic plan } \\
\text { should highlight the quality of } \\
\text { teachers of mathematics to be } \\
\text { produced at MUCE. }\end{array}$ & 6 & 3 & 0 & 4 & 2 & 2.9 \\
\hline
\end{tabular}

Table 16 Analysis of mathematics students' response for question 4: How can the mathematics department at MUCE implement and enhance strategic planning?

\begin{tabular}{llllllll}
\hline S/No & Statement & $\begin{array}{c}\text { Strongly } \\
\text { Agree }\end{array}$ & Agree & Uncertain & Disagree & $\begin{array}{l}\text { Strongly } \\
\text { Disagree }\end{array}$ & Mean \\
\hline i & 8 & 1 & 0 & 6 & 0 & 3.1 \\
& $\begin{array}{l}\text { The department should embark on } \\
\text { developing its strategic plan by } \\
\text { learning from other learning } \\
\text { institutions that have strategic plans } \\
\text { The college administration should } \\
\text { encourage the department to engage in } \\
\text { strategic planning by funding strategic } \\
\text { planning activities. }\end{array}$ & 7 & 1 & 0 & 5 & 2 & 2.9 \\
$\begin{array}{l}\text { The department, through the college } \\
\text { administration should partner with }\end{array}$ & 6 & 2 & 2 & 4 & 3 & 2.7 \\
other stake holders in order to develop \\
the strategic plan
\end{tabular}




support the department in its efforts to
viii $\begin{aligned} & \text { develop strategic plans } \\ & \text { The mathematics department should }\end{aligned}$
consider partnering with public
institutions such as the University of
Zambia and the Copperbelt
University already grounded in
strategic Planning in order a develop a
suitable plan

Table 17 Analysis of mathematics lecturers' responses for question 4: How can the mathematics department at MUCE implement and enhance strategic planning?

\begin{tabular}{|c|c|c|c|c|c|c|c|}
\hline S/No & Statement & $\begin{array}{c}\text { Strongly } \\
\text { Agree }\end{array}$ & Agree & Uncertain & Disagree & $\begin{array}{l}\text { Strongly } \\
\text { Disagree }\end{array}$ & Mean \\
\hline $\mathrm{i}$ & $\begin{array}{l}\text { The department should embark on } \\
\text { developing its strategic plan by learning } \\
\text { from other learning institutions (Private } \\
\text { and public) that have strategic plans }\end{array}$ & 9 & 0 & 0 & 4 & 2 & 3.3 \\
\hline ii & $\begin{array}{l}\text { The college administration should } \\
\text { encourage the department to engage in } \\
\text { strategic planning by funding strategic } \\
\text { planning activities }\end{array}$ & 7 & 2 & 0 & 6 & 0 & 3.1 \\
\hline iii & $\begin{array}{l}\text { The department, through the college } \\
\text { administration should partner with other } \\
\text { stakeholders in order to develop the } \\
\text { strategic plan }\end{array}$ & 8 & 1 & 1 & 2 & 4 & 2.9 \\
\hline iv & $\begin{array}{l}\text { The college should facilitate for training } \\
\text { of members of mathematics in strategic } \\
\text { planning }\end{array}$ & 5 & 3 & 0 & 6 & 1 & 2.8 \\
\hline $\mathrm{v}$ & $\begin{array}{l}\text { The department should scan the } \\
\text { environment in order to find out more on } \\
\text { its Strengths, Weaknesses. Opportunities } \\
\text { and Threats }\end{array}$ & 7 & 2 & 0 & 4 & 2 & 2.9 \\
\hline vi & $\begin{array}{l}\text { The department should compare with } \\
\text { what other competing institutions are } \\
\text { doing }\end{array}$ & 6 & 2 & 1 & 4 & 3 & 2.7 \\
\hline vii & $\begin{array}{l}\text { The government should encourage and } \\
\text { support the department in its efforts to } \\
\text { develop strategic plans }\end{array}$ & 6 & 3 & 0 & 1 & 5 & 2.7 \\
\hline viii & $\begin{array}{l}\text { The mathematics department should } \\
\text { consider partnering with public } \\
\text { institutions such as the University of } \\
\text { Zambia and the Copperbelt University } \\
\text { already grounded in strategic planning. }\end{array}$ & 8 & 1 & 0 & 5 & 1 & 3.1 \\
\hline
\end{tabular}

Finally, the results in table 17 demonstrated that nearly all the factors are significant to the implementation of strategic plan for the mathematics department at MUCE.

Looking at the results from table 10 through to table 17 , the researcher interpreted the results in relation to the four research questions as follows:

\section{Question 1}

Question 1 was about whether the mathematics department needed strategic planning to operate effectively and efficiently. From the analysis above, it is very clear that the department needs to engage in strategic planning. Although, the students and lecturers responses to question 1 suggested that the department is satisfied with the current planning system; tables 2 and 3, responses to question 3 suggested to the contrary. Refer to table 6 and 7 and 14 and 15 . In fact this was further confirmed during the focus group interview with the lecturers who admitted that they know very little about strategic planning. Therefore, the mathematics department at MUCE desperately needs to engage in strategic 
planning and also develop a strategic plan.

\section{Question 2}

Question 2 was to investigate why the mathematics department at MUCE was unable to develop a strategic plan?

Responses to this question has pointed to the fact that, the department is unable to develop a strategic plan because of a good reputation that the college and in particular the mathematics department has built for itself over the few years it has existed as a secondary teacher training college. That is to say, the department finds it easy to recruit trainee teachers. Data in tables 4 and 5 as well as 12 and 13 attested to this. The other reason was that students of mathematics trained at MUCE, are easily employed by government or private secondary schools as compared to those trained from other colleges. The fact that there is a shortage of mathematics teachers in secondary schools in Zambia makes it even easier for MUCE trained graduates to be employed.

\section{Question 3}

Question3 was about finding out from the respondents what components of a strategic plan will be ideal for the mathematics department's strategic plan at MUCE. For this question the two groups of respondents agreed to the statements guiding this question. They agreed for instance that, the vision and mission statements of the department must be developed. Apart from this, respondents also agreed that goals and values should be included in the strategic plan of the department. Finally, the respondents also agreed that quality issues should be part of the department strategic plan and that the department should conduct an environment scan (SWOT) analysis even if it's content or satisfied with current position. Refer to tables 6 and 7 and also 14 and 15.

\section{Question4}

Question 4 aimed at finding ways the mathematics department at MUCE would implement and enhance strategic planning.

According to the respondents' responses, the following were the ways suggested: Actual development of the strategic plan for the department, bench marking public institutions of learning such as the University of Zambia, training of lecturers in strategic management, partnering with other stakeholders apart from government and sourcing for funds to be able to carry out this activity. Tables 8, 9, 16 and 17 together with focus interviews all attest to this.

In conclusion, respondents unanimously agreed that mathematics department should develop a strategic plan to improve its operations and delivery of services to the intended clients. This is the only way the department will remain relevant to the ever changing business environment in Zambia.

\subsection{Recommendations}

From discussions of this research and more so, the findings of the research outlined in chapter 4 , the researcher made the following recommendations:

4.4.1 The department must take a keen interest and embark on developing a strategic plan.

4.4.2 The client organization should be committed to strategic planning and embrace change management in order for strategic planning to succeed.

4.4.3 The government through the client organization must encourage the mathematics department to develop a strategic plan for the department

4.4.4 The client organization should engage in capacity building in strategic planning for the lecturers in the mathematics department. This is very important if the department is to succeed in strategic planning. Olum (2002) writing on the challenges of strategic management at Makere University observed that although the university was funding some of its academic staff in various universities . . ., the number of academic staff that possess requisite skills in the area of strategic planning and management are still inadequate.

4.4.5 The mathematics department should partner with University of Zambia as well as benchmark other leading institutions in strategic planning.

4.4.6 The research should be extended to other colleges of education in Zambia because the problem of strategic planning in public institution is real.

\section{Conclusion}

This research was targeted at investigating why the mathematics department at MUCE was unable to engage in strategic planning. The researcher has revealed that there has never been a written strategic plan for the department since the college was upgraded to a secondary teacher training college in 2008. For this reason, the department is unable to use strategic planning in its planning. Worse still, mathematics lecturers have little or no knowledge about strategic planning. 
For this reason, their input to the research was not significant especially during face to face interviews. Besides this, the researcher also discovered that the college had no written strategic plan since 2008. Despite this situation, the client organization confirmed that the college does engage in annual strategic planning. But was quick to point out that, yearly strategic planning was not good but five year plans were much more ideal. The client organization also highlighted that, this planning was done provincially by all government departments and not at institutional level. For this reason, there was no decentralized strategic planning in institutions. In view of this, the researcher concluded that this could be one of the reasons why the Mathematics department is unable to engage in strategic planning.

All in all, the research has established that, the mathematics department at Mufulira college of Education is operating without a strategic plan. To this effect, there is an urgent need for the department to develop one to enable it operate much more efficiently than it is doing currently.

Limitations

As a result of little knowledge on strategic planning by mathematics lecturers at MUCE as well as lack of financial resources, a strategic plan for the department was not developed as intended.

\section{Acknowledgements}

I' $\mathrm{m}$ greatly indebted to Mr. Rene Lessen, my supervisor under whose direction and guidance this work has come to fruition. I would sincerely like to express my heartfelt gratitude to him for his patience, in-depth constructive criticisms and valuable suggestions, which contributed to the success of this work. I wish to extend my thanks to Mr. Erasmus Kwenge for taking an interest in my work by proof reading the article and for his valuable advice.

Special thanks go to all members of the mathematics department at MUCE and the client organization for allowing me to conduct this research at the institution.

Finally, I would also like to passionately thank the students who volunteered to take part in this study. To you all I say, God bless you abundantly.

\section{References}

Albanese, R. (1975). Management: Toward Accountability.

American Psychological Association. (1972). Ethical standards of psychologists. Washington, DC: American Psychological Association.

Anderson, C. A., Gentile, D.A., \& Buckley, K. E. (2007). Violent video game effects on children and adolescents: Theory, research and public policy. http://dx.doi.org/10.1093/acprof:oso/9780195309836.001.0001

Barry, B. (1986). The Strategic Planning workbook for Non- profit organizations

Beck, C. A. J., \& Sales, B. D. (2001). Family mediation: Facts, myths, and future prospects. Washington, DC: American Psychological Association.http://dx.doi.org/10.1037/10401-000

Bernstein, T. M. (1965). The careful writer: A modern guide to English usage (2nd ed.). New York, NY: Atheneum.

Bjork, R. A. (1989). Retrieval inhibition as an adaptive mechanism in human memory. In H. L. Roediger III, \& F. I. M. Craik (Eds.).Varieties of memory \& consciousness (pp. 309-330). Hillsdale, NJ: Erlbaum.

Bryson, J. M. (1998).A Strategic Planning process for Public and Non-profit Organizations

Copperbelt College of Education (Mukuba University). Strategic plan 2008-2011

Copperbelt University (CBU). Strategic Plan; March, 2009-2013

Cress, C. M. (2009). Curricular strategies for student success and engaged learning [PowerPoint slides]. http://www.vtcampuscompact.org/2009/TCL_post/presenter_powerpoints/Christine\%20Cress\%20-\%20Curricular $\% 20$ Strategies.ppt

Dooris, M. J. (2004).Two Decades of Strategic planning

Driedger, S. D. (1998, April 20). After divorce. Maclean's, 111(16), 38-43.

Gibbs, J. T., \& Huang, L. N. (Eds.). (1991). Children of color: Psychological interventions with minority youth. San Francisco, CA: Jossey-Bass.

Gilbert, D. G., McClernon, J. F., Rabinovich, N. E., Sugai, C., Plath, L. C.,Asgaard, G., ,.. Botros, N. (2004). Effects of quitting smoking on EEG activationand attention last for more than 31 days and are more severe with stress,dependence, DRD2 A 1 allele, and depressive traits. Nicotine and Tobacco Research, 6, 249-267. http://dx.doi.org/10.1 080/1462220041 0001676305 
Goleman, D. (2009). What makes a leader? In D. Demers (Ed.), AHSC 230: Interpersonal communication and relationships (pp. 47-56). Montreal, Canada: Concordia University Bookstore. (Reprinted from Harvard Business Review, 76(6), 93-102, 1998).Griffith University

Guignon, C. B. (1998). Existentialism. In E. Craig (Ed.), Routledge Encyclopedia of Philosophy, 3, 493-502. London, England: Routledge. Hacettepe Oniversitesi Egitim Fakultesi Dergisi, 11, 137-148

Hayward, F. M., \& Ncayiyana, D. J. (2003).A Guide to Strategic Planning for African Higher Education Institutions Higher Education: The Case of Portugal Illinois: Richard D Irwin, Inc.

Kalpic, B. (2002). Strategic Management Theory and Application

Kathleen, P. A. (2003).Strategic Planning in the University

Klimoski, R., \& Palmer, S. (1993). The ADA and the hiring process in organizations. Consulting Psychology Journal: Practice and Research, 45(2), 10-36. http://dx.doi.org/10.1037/1061-4087.45.2.10

Kubrick, S. (Director). (1980). The Shining [Motion picture]. United States: Warner Brothers.

Lawlor, J.E. The Importance of Strategic Planning London: Observatory on Borderless Higher education Long Range Planning, 21(1), 73-81

MacIntyre, L. (Reporter). (2002, January 23). Scandal of the Century [Television series episode]. In H. Cashore (Producer), The fifth estate. Toronto, Canada: Canadian Broadcasting Corporation.

McLuhan, M. (1970a). Culture is our business. New York, NY: McGraw-Hill.

McLuhan, M. (1970b). From cliche to archetype. New York, NY: Viking Press.

Mellers, B. A. (2000). Choice and the relative pleasure of consequences. Psychological Bulletin, 126, $910-924$. http://dx.doi.org/10.1037/0033-2909.126.6.910

Ministry of Education, Science, Vocational, Technical and Early child Education (MESVTEE), strategic plan 2003 2007, New Directions for Higher Education, 63, 5-14.

Newman, F., \& Couturier, L. (2002).Trading Public Goods in Higher Education Market.

Nezahat, G. (1995).Strategic Planning in Higher Education

Olum, Y. (2002). Strategic Management in Institutions of Higher Learning:Planning for Higher Education, 31( 2), 6-32.

Postman, N. (1979). Teaching as a conserving activity. New York, NY: Delacorte Press.

Postman, N. (1985). Amusing ourselves to death: Public discourse in the age of show business. New York, NY: Viking.Practical Decisions Research in Higher Education Journal

Rowley, D, Dolence, M., \& Lujan, H. (1997).StrategicchangeinColleges \& San Francisco: Jossey- Bass.

Semenak, S. (1995, December 28). Feeling right at home: Government residence eschews traditional rules. Montreal Gazette, p. A4.

Shirley, R. C. (1988). Strategic Planning: An Overview.St. Paul, MN: The Amherst H. Wilder Foundation, Sunnyside: Centre for Higher Education Transformation;

Taylor, J. S., \& Machado, M. The struggle for strategic planning in European The Case of Makerere UniversityUniversities: Planning to survive \& prosper. University of Wisconsin System Board of Regents. University of Zambia (UNZA). strategic plan 2013-2017

\section{(cc) BY}

This work is licensed under a Creative Commons Attribution 3.0 License. 